Ritrýnd grein birt 02. september 2020

\title{
Söngleikur sem félagslegur vettvangur
}

\author{
Rannveig Björk Porkelsdóttir og Sólveig Pórðardóttir
}

Abstract $>$ Um höfundana $\rightarrow$ About the authors $\rightarrow$ Heimildir

\begin{abstract}
Markmið pessarar rannsóknar er tvípætt: Annars vegar að skoða félagslegan ávinning söngleikjapátttöku og mikilvægi söngleikjaforms sem óhefðbundins náms og hins vegar að skoða hvaða áhrif söngleikjapátttaka hefur á félagskvíða hjá nemendum með frammistöðukvíða. Rannsóknin var eigindleg viðtalsrannsókn par sem viðtöl voru tekin við unglinga í grunnskóla sem tóku pátt í söngleik. Pá voru dagbókarfærslur rannsakanda einnig hluti af gögnum sem og reynsla hans á vettvangi. Niðurstöður sýna að óhefðbundið nám í söngleiksuppfærslu er mikilvægur vettvangur til að efla félagsfærni nemenda. Jafnframt hefur söngleikjapátttaka góð áhrif á félagskvíða og eflir samskiptafærni nemenda. Pá sýndu niðurstöðurnar að söngleikur er mikilvægur vettvangur fyrir nemendur til að kynnast og losa um hömlur. Jafnframt hefur pátttakan jákvæð áhrif á félagsfærni og minnkar félagskvíða en margir nemendur upplifðu aukið öryggi í félagslegum samskiptum í gegnum söngleikjaferlið. Niðurstöðurnar eru mikilvægar til að sýna fram á hversu nauðsynlegt er að efla óhefðbundið nám og listgreinar og til að styrkja félagsfærni og sjálfstraust nemenda. Jafnframt skipta pær máli til að hjálpa félagskvíðnum nemendum par sem félagskvíði byggir meðal annars á félagslegri fullkomnunaráráttu sem lýsir sér helst á pann veg að nemendur eru hræddir við að gera „samskiptamistök“. Söngleikur, par sem eiga sér stað mikil samskipti, er bví gagnlegur jafnt sem krefjandi vettvangur fyrir pá félagskvíðnu.
\end{abstract}

Efnisorð: Söngleikur, leiklist, félagsfærni, listgreinar, óhefðbundið nám

\section{Inngangur}

„Hamingja og gleði liggja í pví að finna hæfileikum sínum farveg og fá að njóta sín sem einstaklingur og hluti af heild“" (Mennta- og menningarmálaráðuneyti, 2013, bls. 24). Robin Dunbar og fleiri halda pví fram að söngleikur sé félagslegur vettvangur og oft myndist öflug liðsheild á meðal einstaklinga í gegnum slíkt ferli par sem nemendur tengist oft sterkum böndum. Degar einstaklingar syngi saman, til dæmis í kór, tengist peir oft í gegnum sönginn. Dví geti félagsleg samkoma fæett af sér gód félagsleg tengsl (Dunbar o.fl., 2012). Í pessari grein, sem byggir á meistararitgerð Sólveigar Dórðardóttur, verða færð rök fyrir pví hvers vegna pátttaka nemenda í söngleikjum er mikilvæg. Mikilvægi rannsóknarinnar felst 1 að áhrif listgreina og söngleikjapátttöku á félagsfærni, sjálfsmynd og félagskvíða ungmenna hafa lítt verið rannsökuð. Í gegnum listgreinar læra nemendur á annan hátt og vinna með lausnamiðaða og skapandi hugsun. Sköpunargleði eykur einnig námsáhuga pegar börn og ungmenni skynja merkingu viðfangsefnanna og tilgang peirra (Mennta- og menningarmálaráðuneyti, 2013). Mikilvægt er að nemendur finni hvernig hægt er að læra á fjölbreyttan hátt með sampættingu ólíkra námsgreina eins og að nota kennsluaðferðir leiklistar í tungumálanámi. Nemendur efla pannig skilning frá ólíkum sjónarhornum og unnið er með marga færnipætti samtímis, svo sem hlustun, lestur og skrif. Í gegnum listgreinar fá nemendur meðal annars tækifæri til að kynnast mismunandi menningu 
og ólíkum gildum einstaklinga innan samfélags og í umhverfinu. Jafnframt uppgötva peir hvað felst í fegurð og ljótleika eða ást og hvers kyns ofbeldi (Mennta- og menningarmálaráđuneyti, 2013). Dessari grein er ætlað að svara eftirfarandi rannsóknarspurningu: Hvaða áhrif hefur söngleikjapátttaka á félagsfærni og sjálfsmynd unglinga? Markmið rannsóknarinnar var að skoða félagslegan ávinning söngleikjapátttöku og hvaða áhrif söngleikjapátttaka hefði á félagskvíða hjá nemendum, með áherslu á frammistöðukvíða. Leitast var við að varpa ljósi á hvort söngleikir væru mikilvægur vettvangur til að efla félagsproska unglinga, sem og að styrkja sjálfsmynd peirra, og hvort hægt væri að styðja betur við nemendur sem finna sig ekki í hefðbundnu námi, leggja áherslu á styrkleika peirra í listgreinum og finna peim farveg innan skólans.

\section{Söngleikir}

Í gegnum listgreinanám öđlast nemendur ákveðna færni sem peir fá síður í gegnum aðrar greinar. Nám í tónlist hefur jákvæð áhrif á námsgetu nemenda og samskiptafærni sem gagnast einnig innan annarra námsgreina (Shafer og Blakeslee, 2000). Samkvæmt Ann Bamford (2009) er ávinningur listgreina í námi mikill; auk pess að pjálfa nemendur í list og sköpun bjóða pær nemendum upp á aðra nálgun í náminu og víkja frá hinu hefðbundna bóknámi. Nemendur verða virkir pátttakendur í eigin námi sem ýtir undir áhuga og sjálfsálit peirra eykst pví peir purfa að taka áhættu í náminu (Bamford, 2009). Dunbar o.fl. (2012) benda á að söngur og annars konar tónlistarflutningur hefur próast í gegnum árin og orðið að félagslegum vettvangi par sem einstaklingar tengjast í gegnum tónlistina. Í gegnum félagsleg samskipti öðlast nemendur tilfinningagreind. Hugtakið er vítt en í pví felst meðal annars að búa yfir hæfni til að ráða í innstu tilfinningar annarra og búa yfir góðri samskiptagreind (Goleman, 2000). Í gegnum samvinnu eflist sú greind; til dæmis pegar nemendur semja tónlist í hópi purfa peir að hlusta eftir pví hvernig aðrir tjá sig, taka eftir innkomum og hljóðstyrk. Hægt er að líkja pví við að lesa í svipbrigði annarra. Í samspili purfa nemendur pví að lesa í pá sem spila með peim og æfa pannig tilfinningagreind sína sem og félagsfærni. Nemendur eru pví hluti af heild par sem peir læra að virða að hver og einn hefur sitt rými en allir stefna að sama markmiði. Dví myndast öflug liðsheild innan tónlistarhóps par sem nemendur efla tilfinningagreind sína. Wynnpaul, Abrami og Upitis (2016) telja ávinning söngleikjapátttöku geta verið langvarandi fyrir nemendur og að ferlið geti hjálpað peim að próa með sér sjálfsvitund í sköpun, að taka áhættu og öðlast eignarrétt á ferlinu og lokaafurð. Í söngleikjum er heildarmyndin mikilvæg og parf að huga að páttum eins og förðun, búningum, miðasölu, æfingum og alls kyns smáatriðum. Dá gerir pað reynsluna raunverulega fyrir nemendur og áhugaverðari fyrir vikið. Dví er mikilvægt að nemendur fái að sýna afurðina eftir langt og strangt æfingatímabil.

\section{Leiklist}

Leiklist er list augnabliksins. Með leiklist er hægt að takast á við pau mál sem efst eru á baugi í samfélaginu hverju sinni og brenna á nemendum (Mennta- og menningarmálaráðuneytið, 2013). Í gegnum leiklist geta nemendur spreytt sig á mismunandi hlutverkum í ólíku félagslegu samhengi. Í gegnum hlutverkaleik geta nemendur rannsakað hvað pað merkir að vera manneskja (Rannveig Björk Dorkelsdóttir, 2016a). John O’Toole og Joan O’Mara (2007) tala um prjár víddir í tilgangi náms í leiklist, út frá sköpun (e. making) p.e. að semja handrit, leikstýra eða hanna; koma fram (e. presenting), p.e. að setja eitthvað fram, eins og leikarar á sviði, og svörun (e. responding). Hið síðasttalda vísar til sambands leikara og áhorfenda meðan á leiksýningu stendur og hvernig peir bregðast hver við öðrum. Markmiðið er að læra í gegnum leiklist og er lögð áhersla á reynslu nemenda, en ekki á afurðina sjálfa eða lokaútkomu eins og pegar sýnt er leikrit fyrir áhorfendur (Rannveig Björk Porkelsdóttir, 2016b). Rannveig Björk Porkelsdóttir (2012) segir í bók sinni Leikið með listina að í gegnum hlutverkaleik læri nemendur að unnt sé að túlka meiningu orða á annan hátt en bókstaflega: Peir læra að takast á við ímyndaðar aðstæður og pjálfast í skipulagðri og markvissri samvinnu sem eflir félagsproska. Deir pjálfast í notkun talaðs máls, verða sjálfstæðari í vinnubrögðum og læra að koma fram. Degar börn taka pátt í leiklist 
leitast pau við að skilja og viðurkenna samhengi milli menningar og gilda. Pau læra að leita að dulinni meiningu og uppgötva mismunandi pætti lífsins (Rannveig Björk Dorkelsdóttir, 2012). Leiklistin styður nemendur í að tjá, móta og miðla hugmyndum sínum og tilfinningum par sem áhersla er lögð á næmi skynjunar, meðal annars á pví fagurfræðilega, úrvinnslu tilfinninga, eflingu ímyndunarafls og hæeni til tjáningar og samskipta. Pannig skerpist samfélagsvitund peirra og peir eru virkjaðir til lýðræðislegrar pátttöku (Rannveig Björk Porkelsdóttir, 2016a).

\section{Félagskvíði}

Kvíði (e. anxiety) er eðlilegt viðbragð við streitu og getur hann verið gagnlegur við vissar aðstæður, til dæmis við prófundirbúning. Kvíði getur jafnframt varað einstaklinga við hættum í umhverfinu og hjálpað við að halda athygli (Parekh, 2017). Talað er um kvíðaröskun pegar kvíðinn hamlar viðkomandi í daglegu lífi og fer yfir eðlileg mörk. Pá umbreytist hann í ótta og prálátar kvíðahugsanir í miklum mæli. Kvíðaraskanir hafa áhrif á næstum prjátíu prósent fullorðinna á einhverjum tímapunkti í lífi peirra. Hins vegar eru til ýmsar áhrifaríkar meðferðir við kvíða og hjálpa pær langflestum að lifa eðlilegu lífi (Parekh, 2017). Algengasta kvíðaröskunin er félagskvíði (samskipta- og frammistöðukvíði) (e. social anxiety disorder) og hrjáir hann um tólf prósent fólks einhvern tímann á ævinni (Wittchen og Fehm, 2003). Pá er átt við prálátan kvíða 1 félagslegum aðstæðum par sem frammistaða kann að vera metin af öðrum. Dessar aðstæður eru sniðgengnar eða praukað í peim prátt fyrir mikinn kvíða. Margir glíma við félagskvíða í daglegu lífi. Algengt er að peir sem pjást af félagskvíða séu haldnir ótta við að tala í hópi fólks og hitta nýtt fólk (Parekh, 2017). Einkenni félagskvíða koma venjulega fram við unglingsaldur og er mikilvægt að leita sér hjálpar, annars er hætt við pví að kvíðinn vari alla ævi. Aðeins um helmingur peirra sem glíma við félagskvíða leitar sér aðstoðar, venjulega 10 til 21 ári eftir að ljóst er að kvíðinn hamlar daglegu lífi. Detta er merkilegt í ljósi pess að félagskvíðinn hefur verulega neikvæð áhrif á lífsgæði og veldur mikilli vanlíðan (Wittchen og Fehm, 2003).

\section{Leiklistarmeðferð í gegnum spuna}

Robert J. Landy (1994), einn helsti sérfræðingur í notkun leiklistarmeðferðar (e. drama therapy), hefur bent á meðferðarlegt gildi leiklistar. Samkvæmt honum hefur bað að spinna munnlega í leiklist kvíðalosandi áhrif. Pátttakendur ná að skapa fjarlægð milli hversdagslegs veruleika og veruleika ímyndunaraflsins (Holmwood, 2014). Leiklist getur pví haft meðferðarlegt gildi og minnkað kvíða (Landy, 1994). Í bókinni The Mindful Brain (2007) fjallar Daniel J. Siegel um jákvæð áhrif spuna á kvíða. Ástæðan fyrir jákvæðum áhrifum spuna á kvíða er sú að framheilinn (e. the medial pre-frontal cortex) er mjög virkur í spuna og getur haft pau áhrif að einstaklingar verða afslappaðri í samskiptum við aðra. Pá reynist sumum félagskvíðnum einstaklingum auðveldara að vera innan um fólk í hlutverki pví peir upplifa sig frjálsari og hlutverkið hefur ekki „neikvæðar afleiðingar“ líkt og í daglegu lífi par sem einstaklingar eru dæmdir af öðrum (Siegel, 2007). Sóley Dröfn Davíðsdóttir (2017), heldur pví fram að hlutverkið veiti pannig vissa vernd gagnvart mati annarra sem félagskvíðnir eru hræddir við. Félagskvíðnir einstaklingar ná gjarnan að gleyma sér í leik, pá færist athyglin frá pví að vera ofurmeðvitaðir um sjálfa sig yfir í að einbeita sér að ákveðnum leik. Í gegnum leiklist og hlutverkaleik upplifa einstaklingar ákveðna pversögn; ég er ég og ekki ég á sama tíma (Landy, 1991). Pá rímar pað við kenningar Sóleyjar Drafnar Davíðsdóttur (2017) um pau „samskiptamistök“ sem félagskvíðnir eru hræddir við og setja ofurkröfur á sjálfa sig í félagslegum samskiptum (Sóley Dröfn Davíðsdóttir, 2017). Leiklist og spuni í leiklist hefur pví meðferðarlegt gildi og virðast pau áhrif sem koma fram í peim aðstæðum í takt við pað sem gerist á vissum svæðum í heilanum (Siegel, 2007).

Í spuna parf leikarinn að láta til skarar skríða án pess að vita næsta skref. Hann veit ekki hvernig mótleikarar hans munu bregðast við og vinna peir pví að próun atburðarásar saman í flæði. Spuni byggist pannig á mikilli samvinnu og er ferli í mótun (Sawyer, 2003). Ferlið er pví ófyrirsjáanlegt í fyrstu. Degar líður á pað slípast senur til og pað verður fyrirsjáanlegra. Hins vegar getur margt 
komið upp á í skapandi ferli og leikarar ná ekki árangri nema að vera tilbúnir til að taka áhættu, hvernig svo sem lokaútkoman verður (Sawyer, 2003). Bermant (2013) lagði áherslu á líkindi á milli spunaleikhúss (e. improv) og hagnýtrar sálfræði (e. applied psychology). Seinna hugtakið merkir að aðferðir sálfræðinnar eru notaðar, meðal annars til að leysa mannleg vandamál (sjá vef American Psychological Association, 2019). Samkvæmt Bermant eru petta tvær aðferðir sem hægt er að nýta við lausn daglegra erfiðleika, til dæmis kvíða. Spuni er pví félagslegt fyrirbæri og er líkt og samfélag. Dannig færast nemendur frá pví að taka áhættu á litlu sviði innan verndaðs umhverfis og út í lífið par sem hið raunverulega „stóra svið“ lítur dagsins ljós (Bermant, 2013). Blackie og félagar (2014) rannsökuðu spuna undir yfirskriftinni „Act well to be well“. Samkvæmt peirri rannsókn hefur spuni og hlutverkaleikur meðferðarlegt gildi og hefur áhrif á að byggja upp sjálfsmynd pátttakenda. Jafnframt sýndu niðurstöður rannsóknar að spuni (e. improvisation) hefur sjálfstyrkjandi áhrif á pátttakendur (Blackie o.fl., 2014).

\section{Framkvæmd rannsóknarinnar}

Aðferðafræði rannsóknarinnar sem pessi grein byggir á er eigindleg (e. qualitative research). Eigindleg aðferðafræði miðar að pví að rannsaka mannlega hegðun og samskipti á milli fólks (Lichtman, 2013). Tekin voru óstöðluð, hálfopin viðtöl við nemendur á unglingastigi í grunnskóla í Reykjavík til að varpa ljósi á skoðanir peirra og upplifun á pátttöku í söngleik (e. semi-structured interview) með nokkrum stöðluðum spurningum. Sami spurningalisti var notaður í öllum viðtölunum en rannsakandi umorðaði eða aðlagaði spurningarnar að hverjum einstaklingi eins og viðtalið kallaði á (e. guided interview). Einnig hélt rannsakandi dagbók sem var rituð meðan á söngleikjaferli stóð og var hún skrifuð nánast daglega meðan á æfingum söngleiks stóð, í sjö vikur.

\section{Pátttakendur og greining gagna}

Tilgangsúrtak var notað í rannsókninni par sem peir viðmælendur voru valdir sem hentuðu best fyrir markmið hennar. Viðmælendur voru pátttakendur í söngleik innan skólans. Pátttakendur söngleiks voru um sjötíu nemendur í 8., 9. og 10. bekk. Viðmælendur voru valdir út frá reynslu rannsakanda. Hann hafði kynnst peim í gegnum æfingar á söngleiknum og valdi nokkra peirra með tilliti til pess hvernig peir birtust honum í samskiptum við aðra innan söngleiks. Tekið var viðtal við sjö nemendur, fjórar stúlkur og prjá drengi, og voru peim öllum gefin dulnefni til að peir pekktust ekki. Viðmælendur voru spurðir að pví hvort peir hefðu fundið fyrir félagskvíða (samskipta- og frammistöðukvíða) á einhverjum tímapunkti á grunnskólagöngu sinni, hvort peir glímdu enn við hann og hvort peir hefðu fundið fyrir félagskvíða í söngleikjaferlinu. Skráning og úrvinnsla gagna fór fram í mars og apríl 2018. Stuðst var við túlkandi greiningu gagna (e. interpretational analysis) sem er algeng aðferð til að greina gögn innan eigindlegra tilviksrannsókna. Áhersla er pá lögð á að greina pemu í gegnum niðurstöður rannsóknar en pau hjálpa til að lýsa viðfangsefninu. Pemun, p.e. mikilvægi listgreinakennslu, birtingarmyndir félagskvíða, samskipti og vinátta og sjálfsmynd og sjálfstraust, voru síðan flokkuð og grunduð kenning (e. grounded theory approach) notuð til pess að vinna úr upplýsingum og koma auga á pemun (Rúnar Helgi Andrason og Ársæll Már Arnarsson, 2013). 


\section{Niðurstöður rannsóknarinnar}

Hér verður greint frá niðurstöðum rannsóknarinnar. Sett voru fram sérstök greinandi pemu, lýsandi fyrir pað sem fram fór í æfingaferlinu á söngleik. Dví verða niðurstöðurnar kynntar út frá fjórum pemum sem notuð eru sem fyrirsagnir í niðurstöðunum. Fyrst verður greint frá mikilvægi listgreinakennslu, pví næst birtingarmyndum félagskvíða innan söngleiks, pá samskiptum og vináttutengslum og að lokum sjálfsmynd og sjálfstrausti.

\section{Mikilvægi listgreinakennslu}

Niðurstöður rannsóknar sýndu að langflestir pátttakendur vildu að listgreinarnar leiklist og tónlist væru kenndar í grunnskóla. Dá voru flestir sammála um að pær ættu að vera kenndar í vali fremur en sem skyldugreinar. Hins vegar fannst pátttakendum mikilvægt að læra leiklist sem fyrst í grunnskóla til að öðlast meira sjálfstraust við að koma fram á sviði. Pá töldu pátttakendur að pað hjálpaði peim að átta sig á hvað peir vildu verða og hefði pví bein áhrif á framtíðina. Jafnframt kom fram í viðtölum að nemendur nytu sín í verklegum æfingum listgreinanna innan söngleiks enda væru pær uppbrot frá hefðbundnu bóklegu námi. Grunnskólinn sem rannsóknin fór fram í leggur mikla áherslu á leiklist, æfast nemendur bví í að koma fram frá sex ára aldri og töldu pátttakendur pað mikinn kost.

Mér finnst mikilvægt að leiklist sé kennd í grunnskóla líka bara ef fólk hefur sérstaklega áhuga á pví og vill kannski verða eitthvað stórt, leikari eða eitthvað, pá finnst mér að pað ætti að byrja að kenna pað alla vega í grunnskóla. Рað gerir mann líka miklu opnari að leika, pú ert ekki pú sjálfur pannig að fólk fær svona að koma hlutum frá sér og [getur] tjád sig. (Rúnar, viðtal eitt)

Annar pátttakandi rannsóknar var sömu skoðunar og fannst leiklist styrkja sjálfsmyndina í gegnum hlutverk persónu. Kennslan hefði pví reynst honum vel. Dátttakendur voru jafnframt sammála um að leiklist höfðaði sterkt til peirra í grunnskóla, sérstaklega upplifun af leiklistarkennslu og leikuppfærslum skólans. Pátttakendur voru sammála um gagnsemi listgreinakennslu og töldu að peir lærðu að túlka persónur á fjölbreyttan hátt. Deir voru líka sammála um að pað gæeti verið kostur að læra tónlist pví hún hefði áhrif á nemandann á margan hátt. Nemendur læra aðferðir í gegnum tónlist sem geta einnig gagnast í öðrum greinum og á öðrum sviðum, til dæmis í stærðfræði.

Fleiri pátttakendur voru sömu skoðunar og töldu að söngleikjapátttakan virkjaði áhuga peirra, til dæmis á að stunda einhverja af listgreinunum í framtíðinni. Jafnframt væri petta jákvæður félagslegur vettvangur par sem nemendur væru að vinna að einhverju uppbyggilegu. Deir hefðu eitthvað skapandi fyrir stafni og ynnu saman að stórbrotinni sýningu.

Dátttakendur voru allir sammála um að söngleikjaferlið hefði myndað sterka liðsheild. Nokkrir nemendur nefndu að peir hefðu kynnst sérstaklega baksviðs pegar peir voru ekki að leika heldur spjalla inn á milli atriða. Pá kom í ljós við úrvinnslu gagna að pátttakendur áttu góðar minningar eftir söngleikjaferlið og mynduðu tengsl við samnemendur, bæði í gegnum tjáningu á sviði og inn á milli æfinga. Rúnar sagði um pað: „Með pví að leika persónur sem eiga erfitt, til dæmis erfitt heima hjá peim, pá lærirðu að vera önnur manneskja“ (Rúnar, viðtal eitt). Dessi pátttakandi lék persónu sem var hundsuð af öđrum fjölskyldumeðlimum og práđi athygli föđur síns en bróðir persónunnar var í forgrunni og fékk að ráđa öllu á heimilinu. Við að leika petta hlutverk (að sögn Rúnars) fékk hann að upplifa tilfinningar persónunnar sem voru oft erfiðar, hann átti enga vini og var utanveltu í skólasamfélaginu. Rúnar proskaðist pví við að setja sig í spor persónunnar og efldist pannig samkennd hans við að setja sig inn í hlutverkið. Dátttakendur voru sammála um mikilvægi leiklistarkennslu pví pað hjálpaði peim að opna sig með pví að setja sig í hlutverk. Einn nemandinn nefndi til dæmis að leiklistin hefði reynst enn skemmtilegri en hann bjóst við og vakti pað áhuga hans á að læra leiklist í leiklistarskóla. Tveir aðrir nemendur lýstu yfir 
áhuga sínum á að læra leiklist og annar peirra nefndi að söngleikurinn hefði vakið áhuga hans á að læra söng. Pátttakendur voru pví sammála um að söngleikjapátttakan hefði reynst vel sem undirbúningur undir frekara nám.

Í ljós kom að leiklistarkennsla hafði jákvæð áhrif á nemendur á víðtækan hátt. Degar nemendur voru í hlutverki hjálpaði pað peim að opna sig og voru peir óhræddari við að gera mistök eða segja eitthvað vitlaust sem og að opna sig. Pá upplifðu peir sig ekki eins berskjaldaða og fyrir utan sviðið. Rúnari finnst leiklistarkennsla mjög mikilvæg og sagði:

Já, mér finnst pað mjög mikilvægt, pað bara styrkir sjálfstraust, pað lætur pig pora að segja eitthvað og bulla án pess að pað sé verið að gagnrýna pig. Leiklist er líka mikilvæg pví maður kynnist fólki, vita hvað pú vilt gera ef pú tengir ekki við petta, pá bara gott fyrir pig en líka bara hún er svo skemmtileg, pað er svo skemmtilegt að læra svona hluti, að læra að leika, að læra að vera önnur manneskja ... og að vera með stóra rödd og geta sagt eitthvað, leiklist hjálpar mjög mikið með pað. (Rúnar, viðtal eitt)

Allir pátttakendur voru sammála um pann áhuga sem gæti kviknað í gegnum listgreinar og að nemendur uppgötvuðu jafnvel leynda hæfileika sem hjálpuðu peim að halda áfram á peirri braut sem peir kysu. Ljóst er að pað voru viðbrigði fyrir nemendur pegar söngleikjaferli lauk eða líkt og Tristan sagði:

Ég held að petta hafi verið svona: „Ó er petta búið?“ Dú veist, ég var orðinn vanur pví að fara í söngleikinn pannig að ég hugsaði eru engar æfingar eftir, ó nei, pað eru engar! Í síðasta skiptið sem ég setti á mig „,blackface“. (Tristan, viðtal sjö)

Hann tjáði sig jafnframt um líðan fyrir frumsýningu:

Mér leið best á frumsýningu og við vorum að sýna petta í fyrsta skipti og vissum ekki hvort einhver myndi klikka, pökk sé lof enginn klikkaði. Рað var líka skemmtilegt að syngja í fyrsta skiptið, svo venst maður pví og pað verður minna og minna ... (Tristan, viðtal sjö)

Tristani fannst vera munur á pví að leika og syngja; honum líður almennt vel á sviði en hann upplifði sig berskjaldaðri pegar hann söng fyrir framan áhorfendur. Eftir pví sem söngæfingum fjölgaði varð hann öruggari og rödd hans styrkari. Tristani fannst jafnframt mjög gagnlegt að fá æfingu í að koma fram, eins og í söngleiknum, ekki síst til pess að viðhalda áhuga sínum á listgreinum og að öðlast sjálfstraust til pess að læra söng 1 framhaldinu. Pá var hann nokkuð öruggur um hvað hann vildi gera í framtíðinni og fannst pví undirbúningurinn undir frekara nám vera mikilvægur: „Ég er alla vega búinn að læra mikið á Skrekk og söngleiknum út af pví að ég er örugglega að fara að læra að syngja eitthvað í framtíðinni, pá er gott að byrja að læra petta núna“" (Tristan, viðtal sjö). Tristan hélt áfram og ræddi mikilvægi leiklistarkennslu:

Já, pað getur opnað bara persónuleikann eða bara pig, skilurðu? Dannig að pú getur verið að læra eitthvað, til dæmis að pú getur ekki hætt núna ef pú ert aðalpersónan í pessu leikriti, mátt ekki „,baila“ núna. Stundum parf maður að læra að maður parf að gera eitthvað, má ekki „baila“. Рað er líka bara betra að gera pað. (Tristan, viðtal sjö)

Aðrir pátttakendur tóku í sama streng og töluðu um mikilvægi pess að sýna ábyrgð í verki pví peir höfðu tekið að sér að taka pátt í söngleiknum, pá var ekki aftur snúið. Dví jókst ábyrgðartilfinning peirra í gegnum ferlið. Margir pátttakendur voru stressaðir fyrir frumsýningu, sumir meira en aðrir. Rósa tjáđi sig um líðan fyrir frumsýningu:

Ég var mjög stressuð, ég vissi ekki alveg hvort ég gæti petta. Рað var svo mikið að skipta um og mikið af svona og einhvern veginn erfitt að gera petta en svo eftir frumsýninguna langaði mig bara að fá að sýna aftur. (Rósa, viðtal fjögur) 
Fleiri tóku undir petta sjónarmið en ekki var nóg að kunna hlutverkið, heldur purfti að halda athygli og vera í hlutverki allan tímann, líka á meðan aðrir voru að tala á sviðinu. Pá kom í ljós á vettvangi að í nógu var að snúast, bæði leikarar og hljóðmenn burftu að vera á tánum og muna allar skiptingar; hvenær purfti til dæmis að skipta um leikmynd. Dví tóku pátttakendur undir pað sem Rósa sagði að peir hefðu verið spenntir að sýna aftur eftir frumsýningu pví pá vissu peir að sýningin tækist hjá peim og allar skiptingar yrðu betri við hverja endurtekningu.

Dátttaka nemenda efldi sjálfstraust og styrkti sjálfsmynd peirra með pví að takast á við áskoranir söngleiksins. Jafnframt jókst ábyrgðartilfinning pátttakenda við að taka að sér hlutverk og standa sig gagnvart samnemendum sem og leikstjórum sýningar. Einnig kom fram að óvæntur áhugi kviknaði jafnan við að taka pátt í sýningum sem pessum, pví væri mikilvægt að bjóða upp á að taka pátt í söngleikjum innan grunnskólans.

\section{Birtingarmyndir félagskvíða innan söngleiks}

Flestir pátttakendur sögðu að peir fyndu eingöngu fyrir kvíða ádur en peir stigju á svið. Niðurstöður sýndu að kvíðinn hvarf pegar pátttakendur byrjuðu að leika eða syngja á sviðinu og fundu sig í hlutverkinu. Nokkrir pátttakendur sögðu að peir hefðu fundið fyrir góðri orku í salnum og hvatningu til að skemmta áhorfendum. Баð hjálpaði að vera í hlutverki pví pá upplifðu pátttakendur sig ekki eins berskjaldaða líkt og að vera peir sjálfir, án nokkurrar grímu. Deir fundu eingöngu fyrir kvíða í byrjun, eða rétt áður en peir stigu á svið, en pegar peir gleymdu sér í hlutverkinu náđu peir að njóta sín í augnablikinu. Einn nemandinn bar kvíðann, sem hann fann fyrir áður en hann steig á svið, saman við kvíðann sem hann finnur fyrir pegar hann heldur fyrirlestur. Hann fyndi fyrir kvíða meðan á fyrirlestrinum stæði, hann minnkaði ekki. Á hinn bóginn yrði nemandinn afar feginn pegar fyrirlestri lyki en pá yrði mikið spennufall. Á sviði, hins vegar, fyndi nemandinn eingöngu tímabundið fyrir kvíða, rétt á meðan hann kæmist inn í hlutverkið. Síðan gleymdi hann sér í hlutverkinu. Kvíðinn væri pví eingöngu fyrir sýningu en ekki meðan á flutningi stæði. Hér er pví samanburður á ólíkum aðstæðum par sem kvíði blossar upp. Flestir pátttakenda fundu fyrir kvíða uppi á sviði sem hvarf síðan fljótlega eftir að flutningur hófst. Pá sneri kvíðinn að pví hvort frammistaðan yrði nógu góð (frammistöðukvíði). Eftir pví sem á leið og pátttakendur komu fram á fleiri sýningum dró úr kvíðanum. Athena fann til dæmis fyrir kvíða áđur en hún steig á svið og sagði: „Stundum, en kannski ekki beint í söngleiknum, leið mér bara vel á sviðinu. Pað kemur stundum smá kvíði áður en stigið er á svið en hann hættir pegar maður byrjar að syngja eða leika“" (Athena, viðtal sex).

Fleiri upplifðu að líða vel á sviði pegar peir náðu að gleyma sér í hlutverkinu. Pátttakendur voru jafnframt sammála um að leiklistin hjálpaði peim að verða opnari en hins vegar gæti pað reynst félagskvíðnum nemendum erfitt pví einstaklingar neyðast til pess að vera opnir í kringum annað fólk. Athena sagði um pað: „Sumir gætu fengið kvíðakast í kringum annað fólk pví peir ættu erfitt með аð tjá sig við aðra“ (Athena, viðtal sex). Félagskvíðnir nemendur purftu vissulega að skora á sjálfa sig innan söngleikjasamfélagsins og stíga út fyrir pægindarammann. Hins vegar upplifðu peir minni kvíða eftir pví sem peir fengu meiri æfingu í hlutverki og í samskiptum á milli atriða. Hjá Tristani blossaði kvíðinn hins vegar upp eftir sýningu:

Nei, hérna sko ég fann fyrir smá kvíða ... eða sko ég fann ekki fyrir neinum kvíða í söngleiknum, ég er venjulega ekki með neinn kvíða pegar ég er að leika. Ég er bara með smá kvíða eftir á ef ég geri pað ekki nógu vel. Eins og í forkeppninni (í Skrekk) sem kom ekki í sjónvarpið pá var ég ekki í réttri tóntegund allan tímann pannig að pað var ekki mjög skemmtilegt, pá var ég með kvíða eftir á. Ég er venjulega ekki pað stressaður fyrir раð. (Tristan, viðtal sjö)

Hann bætti jafnframt við að uppi á sviði væri hann í sínum pægindahring, í hlutverki. Upplifun hans var pví undantekning frá upplifun hinna pátttakendanna pví peir fundu venjulega fyrir kvíða áður en stigið var á svið. Tristan sagði jafnframt að hann hefði upplifað félagskvíða áður en 
æfingar á söngleiknum hófust, pannig að pátttaka hans hafði jákvæð áhrif á hann pegar á leið. Fleiri pátttakendur nefndu að peir hefðu fundið fyrir óöryggi og félagskvíða í samskiptum við annað fólk áđur en æfingar á söngleik hófust. Dá voru peir litaðir af neikvæðri reynslu í fyrri samskiptum og pví vanir að finna fyrir kvíða í félagslegum samskiptum. Samskiptin í gegnum söngleikinn hjálpuðu pví sérstaklega peim nemendum að opna sig og vera öruggari í samskiptum. Af peim sökum dró töluvert úr félagskvíðanum við pátttöku peirra í söngleiknum. Athena var ein af peim og sagði: „Stundum er ég óörugg í kringum fólk, fólk sem ég pekki ekki nógu vel eða treysti ekki. Ég hef lent í pví í gegnum tíðina að verða illa fyrir einhverju svona pannig að ég hef alltaf smá áhyggjur í samskiptum“ (Athena, viðtal sex). Athenu fannst hún jafnframt verða öruggari í samskiptum við að taka pátt í söngleiknum og að félagskvíðinn hefði minnkað smám saman. Dví hefur hún jákvæðar minningar í farteskinu eftir pátttöku sína í söngleiknum. Athyglisvert var að sjá hvernig hún varð sífellt öruggari í samskiptum eftir pví sem á leið í ferlinu. Athena sagði að hún væri oft kvíðin í kringum fólk en pátttaka hennar í skipulögðu verkefni hjálpaði henni að eiga í samskiptum við fólk og sagði: „Mér finnst ég geta verið meira með fólki 1 gegnum svona verkefni og pað fær mig til pess að tala meira“ (Athena, viðtal sex). Hún sagði jafnframt að hún hefði ekki mikið verið að sækja í að tala við samnemendur í skólanum og að söngleikurinn hefði pví hjálpað henni mikið við að eiga samskipti við til dæmis stelpurnar í bekknum. Söngleikurinn hjálpaði pátttakendum pví að tjá sig við samnemendur og komu margir sjálfum sér á óvart í gegnum ferlið. Sjálfstraust peirra efldist við að koma endurtekið fram á sviði.

Niðurstöður sýna að samvinna innan söngleiks par sem stefnt er að sameiginlegu markmiði getur hjálpað félagslega óöruggum nemendum og peim sem glíma við félagskvíða að upplifa sig sem hluta af hópi. Félagskvíði minnkaði jafnframt hjá pátttakendum og hjálpaði söngleikjapátttakan peim sem höfðu upplifað neikvæð samskipti áður fyrr að brjóta upp neikvætt hugsanamynstur gagnvart pví að eiga í samskiptum í hópi. Stefanía sagði um pað: „Ég held mér líði best uppi á sviði, mér finnst ég geta opnað mig betur. Ég veit ekki alveg hvernig ... en ég er í ákveðnu hlutverki (Stefanía, viðtal prjú). Pá voru flestir henni sammála og fundu fyrir auknu frelsi, sérstaklega pegar peir kunnu hlutverk sitt svo vel að peir gátu farið að spinna aukalega. Flestir pátttakendur voru sammála um að í gegnum leiklist efldist sjálfstraust peirra innan um aðra. Раð sást glöggt á vettvangi á milli æfinga og á sviðinu sjálfu. Söngleikjapátttakan hafði pví jákvæð áhrif á félagskvíða. Um leið jókst félagsfærni hjá pátttakendum og sjálfsmynd efldist. Flestir pátttakendur greindu jafnframt frá pví að frammistöðukvíðinn hefði minnkað í hvert skipti sem peir komu fram á sviðinu; hann hefði verið mestur í byrjun en dofnað pegar viðkomandi byrjaði að leika eða syngja.

\section{Samskipti og vináttutengsl}

Allir pátttakendur voru sammála um að pátttaka peirra í söngleiknum hjálpaði peim að opna sig gagnvart samnemendum í ferlinu og pað hefði góð áhrif á samskipti fyrir utan söngleikinn. Deir töldu að pátttaka peirra í söngleiknum hjálpaði peim að brjótast út úr skelinni. Jafnframt hefðu allir pátttakendur kynnst betur í gegnum ferlið. Mörgum pótti pví miður pegar söngleikjaferlinu lauk eftir síðustu sýninguna. Nemendur voru orðnir vanir pví að hittast á æfingum og pannig myndaðist ákveðin liðsheild innan hópsins. Í tveimur tilfellum hafði söngleikjapátttakan pau áhrif að endurvekja gamla vináttu á milli tveggja einstaklinga; peir höfðu verið vinir áður en tóku upp práðinn í söngleikjaferlinu par sem peir kynntust enn betur og vörðu meiri tíma saman í kjölfarið. Hjá Stefáni kom eftirfarandi fram:

Dað var pannig að ég og Siggi vorum bestu vinir en svo hættum við pví en svo í söngleiknum tengdumst við betur aftur. Nú erum við bestu vinir og pað svona hjálpaði mér. Söngleikurinn svona gerði okkur öll svona bestu vini. (Stefán, viðtal tvö)

Rúnar var sammála og sagði: 
Ekkert smá mikil áhrif, pað var bara, ég porði miklu meira, bara að tala við hvern sem er og petta var bara svona, petta var mjög gott. Mér leið mjög vel. Líka að gera svona styrktaræfingar til pess að kynnast fólki betur, svona pannig ... og pað var ótrúlega pægilegt fattarðu? Út af pví að maður gat pá talað við fólk, ekkert svona vandræðalega. (Rúnar, viðtal eitt)

Aðrir pátttakendur voru sammála og sögðu að upphitunaræfingar fyrir æfingu á söngleiknum hefðu hjálpað mikið við að koma sér í gang, samskiptin hefðu öll orðið afslappaðri og nemendur tengst vinaböndum í gegnum ferlið. Dátttakendur voru sammála um að peir hefðu kynnst betur innbyrðis líkt og Rúnar sagði: „Mér fannst pað mjög gott, ég eignaðist fattarðu ... eða ég kynntist fleira fólki betur. Eins og ég eignaðist vin sem er mjög góður vinur minn núna og petta fannst mér mjög gott ferli, ógeðslega skemmtilegt" (Rúnar, viðtal eitt). Dátttakendur voru sammála um að innan hópsins hefði myndast sterk liðsheild og upplifðu peir pví tómleikatilfinningu pegar seinasta sýningin var afstaðin. Ljóst var að söngleikjaferlið hafði djúpstæð áhrif á nemendur og peir vildu taka pátt í slíkri uppfærslu aftur. Sumir voru leiðir og svolítið fegnir á sama tíma pví petta hafði verið mikil vinna meðfram námi og alls konar áhugamálum. Til dæmis voru margir að æfa söng, körfubolta og annað á sama tíma.

Athena sagði:

Mér fannst pað mjög leiðinlegt pví pað var svo gaman að gera petta. Ég fór að gráta af pví að petta var svo gaman og svo leiðinlegt að petta var búið. Ég vildi að við gæetum fengið að gera petta aftur en petta er bara einu sinni. (Athena, viðtal sex)

Stefanía tók í sama streng og sagði: „Mér finnst pað svo leiðinlegt pví ég var búin að kynnast öllum svo vel og svo fer allt aftur að verða venjulegt og pá fara allir svona í burtu“" (Stefanía, viðtal prjú). Nú pyrftu peir að rækta tengslin sem mynduðust í gegnum söngleikinn og hittast undir öðrum kringumstæðum. Rúnar horfði dreyminn út um gluggann og sagðist vera afskaplega ánægður með pá reynslu sem hann öðlaðist í söngleikjaferlinu. Hann hefði kynnst samnemendum náið líkt og aðrir og sagði hann að pátttaka hans hefði hjálpað sér bæði vina- og félagslega.

Ljóst er að söngleikjapátttaka hefur stóran félagslegan ávinning fyrir pátttakendur. Bæði hjálpar pátttakan peim félagslega sem og að eignast vini og jafnvel að endurvekja gamla vináttu. Yngri nemendur í áttunda bekk kynnast nemendum í níunda og tíunda bekk og var söngleikurinn sterkur vettvangur að peirra sögn til pess að kynnast öðrum betur. Pátttakendur voru sammála um að peir vildu upplifa sams konar stemningu aftur og peir upplifðu við vinnu í söngleiknum og jafnframt voru peir pakklátir fyrir reynsluna og pau tengsl sem peir mynduðu.

\section{Sjálfsmynd og sjálfstraust}

Dátttakendur voru allir sammála um að söngleikjaferlið hefði góð áhrif á sjálfsmyndina og að sjálfstraust peirra hefði aukist í gegnum ferlið. Deir tóku fram að peir purftu að hluta til að hafa samskipti við nemendur sem peir pekktu ekki áður og pað hjálpaði peim að vera opnari. Deim pótti pví söngleikjapátttakan hafa góð áhrifá sjálfsmyndina við að stíga út fyrir pægindarammann. Rósa sagði um pað: „Đó pú hefðir ekki endilega talað við krakkana áđur sem eru með pér í senu pá ... svo pað hafði alveg góð áhrif á sjálfsmyndina“" (Rósa, viðtal fjögur). Dóra tók í sama streng og sagði jafnframt að sjálfstraust hefði aukist í gegnum ferlið. Hún sagði að sér hefði pótt erfitt að syngja fyrir framan eldri krakkana í byrjun „... en svo varð pað bara ekkert mál og pá held ég að sjálfstraustið mitt hafi orðið aðeins betra“" (Dóra, viðtal fimm). Dóra hélt áfram og lagði áherslu á að mikilvægt væri að fá pjálfun í að leika á sviði sem fyrst. Í skólanum sem um ræðir byrja nemendur snemma í leiklist og hjálpar pað peim að leika sem unglingar pví pá eru peir með einhverja reynslu af pví að koma fram. Aðrir pátttakendur tóku undir með Dóru og sögðu jafnframt að pótt peir hefðu leikið lítið hlutverk pá hefði pað samt sem áður haft góð áhrif á sjálfstraustið. 


\section{Samantekt og umræða}

Meginviðfangsefni rannsóknarinnar var að skoða félagsleg áhrif söngleikjapátttöku og mikilvægi pess að bjóða upp á óhefðbundið nám innan grunnskólans par sem listgreinarnar tónlist, leiklist og dans væru sampættar í söngleik. Annað markmið rannsóknarinnar var að svara rannsóknarspurningunni um hvaða áhrif söngleikjapátttaka hefur á félagskvíða hjá nemendum með frammistöðukvíða. Meirihluti pátttakenda rannsóknar, sex af sjö talsins, voru ýmist félagslega óöruggir eða félagskvíðnir, að eigin mati. Dó var félagskvíðinn mismikill og sneri aðallega að frammistöðukvíða par sem viðmælendur upplifðu flestir kvíða áður en peir stigu á svið.

Félagskvíði felur í sér að vera hræddur við að gera mistök af ótta við viðbrögð annarra. Fólk með félagskvíða upplifir pað oft vera „samskiptamistök“ ef eitthvað fer úrskeiðis í samskiptum (Sóley Dröfn Davíðsdóttir, 2017). Óvissan í leikferli og í spuna er pví krefjandi fyrir félagskvíðna nemendur. Dað er pví einstaklega gott tækifæri fyrir pá að æfa sig í að takast á við hana í gegnum óvæntar uppákomur í uppsetningu leikrits og taka áhættu í samtölum við mótleikara sína. Slíkar æfingar innan söngleiks eru í raun undirbúningur fyrir óvæntar áskoranir í lífinu og samskipti sem geta valdið kvíða (Bermant, 2013). Pátttakendur söngleiksins unnu stóra félagslega sigra með pví að vinna náið í stórum hópi og minnkuðu pví félagskvíða með pví að ganga í aðstæður í stað pess að sniðganga pær. Niðurstöður rannsóknarinnar benda til pess að pátttakendur sem fundu fyrir félagskvíða hafi ekki fundið fyrir honum uppi á sviði meðan á flutningi stóð, nema rétt í byrjun. Peir náðu að gleyma sér í hlutverkinu. Í gegnum leiklist gátu nemendur spreytt sig á mismunandi hlutverkum í ólíku félagslegu samhengi og um leið gátu peir mátað sig inn í ólík hlutverk og pannig stigið út fyrir pægindarammann (Rannveig Björk Dorkelsdóttir, 2016a). Er pað einnig 1 takt við kenningar Landy (1991) par sem pátttakendur fá tækifæri til að gleyma sér í atburðarás, í gegnum spuna, líkt og gerðist hjá pátttakendum í söngleiknum. Deir eru pví óhræddari við að gera mistök og færa athyglina frá sjálfum sér. Hlutverkið hjálpar viðkomandi að sleppa sér og hugsa peir síður um viðbrögð annarra (Landy, 1994). Deir sem fundu fyrir félagskvíða fengu pví æfingu í að takast á við óvæntar aðstæður í gegnum spuna. Deir æfðust í spuna í gegnum upphitunaræfingar par sem leikarinn parf að spinna án pess að vita framvinduna fyrirfram (Sawyer, 2003). Slíkt getur reynst kvíðnum einstaklingum prekraun (Bermant, 2013). Söngleikjaferlið er síbreytilegt ferli og er pví æfing fyrir félagskvíðna að takast á við óvæntar uppákomur og breytingar pví peim finnst oft ópægilegt að vita ekki fyrirfram hvað gerist. Dví æfir ferlið óvissupolmörk peirra (Sawyer, 2003). Í sumum tilfellum fundu pátttakendur fyrir kvíða, ýmist sérstaklega við að syngja eða tala fyrir framan áhorfendur. Er pað í takt við einkenni félagskvíða en peir sem finna fyrir honum eru oft hræddir við að segja eitthvað vitlaust fyrir framan fólk (Sóley Dröfn Davíðsdóttir, 2017). Dátttakendur rannsóknar voru á unglingsaldri, margir peirra höfðu fundið fyrir félagskvíða áður og glíma enn við hann. Kvíðinn uppgötvast oft í kringum unglingsaldur og skiptir miklu máli að takast á við hann vegna vanlíðunar og skorts á lífsgæðum (Wittchen og Fehm, 2003). Söngleikjaformið er ein aðferð til að glíma við félagskvíða pví sjálfsálit nemenda eykst við að taka áhættu í pví ferli. Er pað í takt við áherslur Bamford um skapandi nám (Bamford, 2009). Mikilvægt er pví að viðhalda söngleikjahefð innan grunnskóla svo peir sem eru óöruggir félagslega eða glíma við félagskvíða fái tækifæri til pess að skora á sjálfa sig og minnka kvíða á peim vettvangi.

Í ljós kom að með pví að taka pátt í söngleiknum styrktist sjálfsmynd nemenda og félagslegt sjálfsöryggi peirra. Kvíði minnkaði í peirra hópi, sérstaklega frammistöðukvíði. Í viðtölunum komu persónuleg viðhorf hvers og eins vel íljós og pátttakendur tjáđu sig óhikað um viðfangsefnið. Dó parf að hafa í huga að nemendur eiga stundum til að svara á pann hátt sem peir halda að henti fullorðnum best og hefur menning og mismunandi félagslegar aðstæður jafnvel áhrifá svör peirra.

Rök fyrir söngleikjapátttöku eru margpætt og ljóst er að færnipættir sem nemendur vinna með í söngleikjum eru heilmargir. Í gegnum ferlið proskast nemendur bæði námslega og persónulega og eflast í félagsfærni í gegnum samvinnu. Tilfinningagreind og samkennd nemenda eflist sem og hæfni peirra til að setja sig í spor ólíkra persóna (Wynnpaul, Abrami og Upitis, 2016). 
Samkvæmt niðurstöðum rannsóknarinnar krefst pað mikils kjarks og hugrekkis að koma fram á sviði og er mikilvægt að nemendur rækti hæfileika sína og fái tilfinningu fyrir styrkleikum sínum á sviði ólíkra greina. Skapandi hugsun og pær aðferðir sem nemendur læra í gegnum söngleikjapátttöku gagnast peim í mismunandi verkefnum sem peir taka sér fyrir hendur í framtíðinni, til dæmis í öðru námi. Deir læra að beita lausnamiðaðri hugsun innan söngleiks pegar upp koma vandamál sem nýtast í daglegu lífi við óvæntar áskoranir. Dessar niðurstöður eru í samræmi við ályktanir Bamford (2009) pess efnis að pegar nemendur verða virkir pátttakendur í eigin námi ýtir pað undir áhuga peirra á náminu og sjálfsálit peirra eykst. Pannig má segja að í gegnum söngleikjapátttöku geti nemendur uppgötvað nýjar hliðar á sjálfum sér og fengið aukinn áhuga á listum almennt.

Leiklistin hjálpar nemendum að pekkja eigin tilfinningar með pví að skoða viðfangsefni sem tengjast lífinu sjálfu með gagnrýnum augum, velta upp ólíkum sjónarmiðum og draga lærdóm af leikferli. Menntun í leiklist snýst um að pjálfa nemendur í aðferðum listgreinarinnar (t.d. spuna, persónusköpun og látbragðsleik) en ekki síður um læsi á leiklist í víðu samhengi og að dýpka skilning nemenda á sjálfum sér, mannlegu eðli og samfélagi (O’Toole, 2015). Leiklist er list augnabliksins. Með leiklist er hægt að takast á við pau mál sem efst eru á baugi í samfélaginu hverju sinni og brenna á nemendum (Mennta- og menningarmálaráduneyti, 2013). Í gegnum leikferli er hægt að takast á við óvissu og er lokaútkoman pví ekki pað eina sem skiptir máli heldur ferðalagið að henni. Рað er krefjandi æfing fyrir pá sem glíma við félagskvíða en peir óttast oft viðbrögð annarra og eiga erfitt með að takast á við óvæntar uppákomur (sjá m.a. Landy 1994; Siegel, 2007). Hins vegar sýndu niðurstöður að pað að setja sig í hlutverk hjálpar peim sem glíma við félagskvíða (samskipta- og frammistöðukvíða) að sleppa sér og prófa sig áfram. Deir sem eru félagskvíðnir reyndust óhræddari við að gera mistök í hlutverki. Í viðtölum kom skýrt fram að peim pátttakendum sem fundu fyrir félagskvíða fannst pægilegt að vinna með fólki í skipulögðu verkefni og pað hjálpaði að vera í hlutverki. Pá ættu peir auðveldara með að tala við fólk á peim forsendum par sem stefnt var að sameiginlegu markmiði.

Dó að nemendur sjái ekki fyrir sér að fara út í listageirann pegar peir verða eldri er pó mikilvægt að kennarinn geri sitt besta við að viðhalda áhuga nemenda í gegnum grunnskólann. Skapandi hugsunarháttur er eftirsóknarverður í hvaða starfsgrein sem er og sú færni sem nemendur læra í gegnum söngleikjapátttöku er pví ómetanleg. Pá myndast sterk liðsheild í gegnum hópsöng líkt og gerist í lokasenu söngleiksins. Nemendur sem eru ekki sterkir á bókina blómstra jafnan í gegnum söngleikinn í verklegum æfingum og finna jafnvel sína fjöl par. Söngleikjapátttaka er proskandi bæði félagslega og námslega en nemendur fá tækifæri til pess að uppgötva nýjar hliðar á sjálfum sér í gegnum samvinnu við söng, leik og dans. Pá eflist tilfinningagreind og samkennd nemenda í gegnum ferlið (Rannveig Björk Dorkelsdóttir, 2016a).

Unglingarnir í söngleiknum eru á viðkvæmum aldri og fara í gegnum erfiðar tilfinningar hver á sínum hraða. Engu að síður mótast peir í gegnum söngleikjaferlið með pví að setja sig í spor persóna. Мeð pví að sameina tónlist, leiklist og dans verður til lifandi kokteill og mismunandi færni sem á pó fjölmargt sameiginlegt. Spuni er til dæmis sameiginlegur í öllum listgreinunum. Í gegnum listgreinarnar stíga nemendur inn í hlutverk og saga er sögð sem fylgir ákveðinn boðskapur. Áhrif listgreina eru margvísleg og samkvæmt pessari rannsókn eru pau yfirleitt jákvæð. Раð mætti pví teljast mikilvægt að efla vægi peirra innan grunnskólans til að skapa gott jafnvægi á milli bóklegra og verklegra námsgreina.

Niðurstöður rannsóknar sýndu glöggt að söngleikur er mikilvægur vettvangur fyrir nemendur til að kynnast og losa um hömlur. Pátttakan hefur jákvæð áhrif á félagsfærni og minnkar félagskvíða en margir nemendur upplifðu aukið öryggi í félagslegum samskiptum í gegnum söngleikjaferlið. Pátttakendur sögðu frá pví í viðtölum að peir hefðu endurvakið vinatengsl í gegnum söngleikjaferlið sem og að sjálfstraust og félagsfærni peirra hefði aukist.

Eins og fram kemur í byrjun pessarar greinar hjálpar ímyndunaraflið félagskvíðnum að fara inn í 
hugarheim annarrar persónu og færa peir pá athyglina frá sjálfum sér og yfir á hana. Á pann hátt hjálpar spuni og leiklist peim sem glíma við félagskvíða að vera í núinu. Pví er söngleikurinn kjörinn vettvangur fyrir pá að skora á sjálfa sig í samskiptum við aðra. Félagskvíðnir glíma við „félagslega fullkomnunaráráttu“ en innan söngleiks er gríðarleg samvinna og ófyrirsjáanlegt ferli sem reynir á pá sem eru kvíðnir og purfa helst að vita allt fyrirfram. Dví skiptir máli að hvetja pá einstaklinga áfram, efla sjálfstraust peirra og félagsfærni. Söngleikjapátttaka er öflug leið til pess að takast á við félagskvíða, líkt og í hugrænni atferlismeðferð pegar fólk með fælni fer og mætir pví sem pað óttast og einstaklingar æfa sig í félagslegum samskiptum. Ljóst er að menntunargildi skólasöngleikja er margvíslegt og hjálpar til að renna enn frekar stoðum undir slíkt nám í grunnskóla og að sampætta tónlist, leiklist og dans í áhrifaríkum suðupotti óhefðbundins náms.

Áhugavert væri að rannsaka enn frekar hvort peir sem glíma við félagskvíða sæki almennt mikið 1 a a taka pátt í söngleikjum eða kjósi hefðbundið meðferðarform, til dæmis hópmeðferð undir leiðsögn sálfræðinga. Рað mætti segja að söngleikur sé ákveðið meðferðarform við félagskvíða par sem ýmislegt getur komið upp á og margir mismunandi einstaklingar koma saman. Pátttakendur rannsóknar voru sammála um að söngleikurinn minnkaði kvíða peirra í kringum fólk, sem og að koma fram. Mikilvægt er pví að halda áfram rannsóknum á félagslegum áhrifum söngleikja.

\section{Social benefits of musical participation}

The aim of this article is to shed light on social benefits of musical participation and the importance of musical form as a non-traditional type of learning, in which the art forms of music and drama are treated as one whole. Another aim is to discover the impact of musical participation by focusing on performance anxiety through drama therapy. Drama therapy can play an important role in helping young people deal with social anxiety. Drama therapy involves a relationship between a therapist and a client or clients who attempt to make sense of their life experience as they engage, partly or fully, in a creative process, in this case through the media of drama and theatre. Robert Landy talks about the role of drama, stating that it is 'about people creating a distance between the everyday reality and the reality of the imagination. Role plays and improvisations can encourage participants to understand negative behaviours and to practice new ways of reacting and of being' (Landy, 1994). He also describes 'the dramatic experience of role as being one of paradox: I am me and not-me at the same time. It is one of engagement and separation' (Landy, 1991). In his study Daniel J. Siegel (2007) reports on the positive effects improvising has on anxiety in the book The Mindful Brain. According to him, the reason for the positive effects of improvising is that the medial frontal cortex is very active when improvising and has the effect that individuals become better in communication with others. Then some social-minded individuals find it easier to be around people in a role because they feel they are freer. At the same time, the role does not have "negative consequences" as in everyday life where individuals are judged by others (Sóley Dröfn Davíðsdóttir, 2017). The research question for this article is: What are the effects of participation in a school musical on social skills and self-perception of adolescents? This was a qualitative interview study in which interviews were conducted with elementary school teenagers who participated in a musical. The investigator's journal entries were also part of the data as well as his experience in the field. All interviewees reported that the musical process had helped them forge connections with one another. Those students who experienced anxiety said that throughout the process, their anxiety had diminished and that it had helped them express themselves to fellow students, enhancing their self- confidence. The results show that non-traditional learning within a musical is an important platform for enhancing students' social skills. Furthermore, musical participation has a positive impact on social anxiety and enhances students' communication skills. Practitioners 
say it can empower people who struggle with communication to express their needs and feelings. It can help to forge relationships by enhancing confidence or bringing people together. It can provide opportunities to experience positive self-esteem and self-worth, and help people gain control over conflicts and anxieties. The results clearly demonstrated the necessity of non- traditional learning and arts in enhancing students' social skills and self- confidence. At the same time, it is important to help students who suffer from social anxiety, since the base of social anxiety is social perfectionism, which is best described by the fact that students are afraid to fail during communication with other people. Music-based projects, in which there is considerable social interaction, are, therefore, a helpful as well as a challenging platform for those who suffer from social anxiety disorder. The study is useful to all those who work in primary and secondary education and consequently important to the school community, especially to those who are socially excluded and often find themselves in the world of creative arts.

Keywords: School musical, drama, social skills, arts education, non-traditional learning.

\section{Um höfundana}

Rannveig Björk Dorkelsdóttir (rbth@hi.is) er dósent í leiklist við Menntavísindasvið Háskóla Íslands. Hún lauk doktorsprófi frá Kennaradeild Norska tækni- og vísindaháskólans (NTNU) í Prándheimi 2016 par sem hún skrifaði um innleiðingu leiklistar í grunnskóla á Íslandi. Rannsóknarsvið hennar tengist meðal annars listkennslu og leiklist.

Sólveig Dórðardóttir (solveig.thordardottir@rvkskolar.is) útskrifaðist frá Háskóla Íslands árið 2019 með M.Ed.- gráðu í grunnskólakennarafræði með áherslu á leiklist og tónlist í skólastarfi. Hún starfar sem leiklistarkennari í Reykjavík.

\section{About the authors}

Rannveig Björk Thorkelsdóttir (rbth@hi.is) is associate professor in drama at the University of Iceland, School of Education. She holds a Ph.D. from the Norwegian University of Science and Technology (NTNU) with emphasis on drama and theatre study. In her research and practice she focuses on drama and artistic approaches to teaching and learning.

Sólveig Thordardóttir (solveig.thordardottir@rvkskolar.is) graduated from the University of Iceland in 2019 with an M.Ed. degree as a teacher in compulsory school with focus on drama in education. She currently works as drama teacher at a compulsory school in Reykjavík.

\section{Heimildir}

American Psychological Association. (2019).Journal of Applied Psychology. Sótt af https://www.apa.org/pubs/ journals/apl/index

Bamford, A. (2009). The wow factor: Global research compendium on the impact of the arts in education. New York: Waxmann Munster.

Bermant, G. (2013). Working with(out) a net: Improvisational theater and enhanced well-being. Frontiers in Psychology, 4(929), 1-3. doi:10.3389/fpsyg.2013.00929 
Blackie, L. E. R., Roepke, A. M., Foregard, M. J. C., Jayawickreme, E. og Fleeson, W. (2014). Act well to be well: The promise of changing personality states to promote well-being. Í A. Parks og S. Schueller (ritstjórar), The Wiley Blackwell handbook of positive psychology interventions (bls. 462-474). New York: Wiley.

Dunbar, R., Baron, R., Frangou, A., Pearce, E., van Leeuwen, E. J., Stow, J., ... van Vugt, M. (2012). Social laughter is correlated with an elevated pain threshold. Proceedings of the Royal Society, Biological Sciences, 279(1731), 1161-1167. Sótt af https://www.ncbi.nlm.nih.gov/pmc/articles/PMC3267132/

Goleman, D. (2000). Tilfinningagreind (Áslaug Ragnars pýddi). Reykjavík: Iðunn.

Holmwood, C. (2014). Drama education and dramatherapy: Exploring the space between disciplines. New York: Routledge.

Landy, R. (1991). The dramatic basis of role theory. The Arts in Psychotherapy, 18(1), 29-41.

Landy, R. (1994). Drama therapy: Concepts, theories, and practices. Springfield, IL: Charles C Thomas.

Lichtman, M. (2013). Qualitative research for social sciences. Los Angeles: SAGE.

Mennta- og menningarmálaráđuneyti. (2013). Aðalnámskrá grunnskóla: Almennur hluti 2011: Greinasvið 2013. Reykjavík: Höfundur.

O'Toole, J. og O'Mara, J. (2007). Proteus, the giant at the door: Drama and theatre in the curriculum. Í L. Bresler (ritstjóri), International handbook of research in arts education (bls. 203-218). Dordrecht: Springer.

O'Toole, J. (2015). When advocacy meets opportunity... what's the reality? Establishing drama in the curriculum. Í M. Fleming, L. Bresler og J. O’Toole (ritstjórar), The Routledge international handbook of the arts and education, (bls. 185-193). London: Routledge.

Parekh, R. (2017). Help with anxiety disorders. Sótt af https://www.psychiatry.org/patients-families/anxiety-disorders

Rannveig Björk Porkelsdóttir. (2012). Leikið með listina. Reykjavík: Háskólaprent.

Rannveig Björk Porkelsdóttir. (2016a). What are the enabling and what are the constraining aspects of the subject of drama in Icelandic compulsory education? Í T. Chemi og X. Du (ritstjórar), Arts-Based Methods in Education Around the World (bls. 231-246). Sótt af https://www.riverpublishers.com/pdf/ebook/chapter/ RP_9788793609372C10.pdf

Rannveig Björk Dorkelsdóttir. (2016b). Understanding drama teaching in compulsory education in Iceland: A micro-ethnographic study of the practice of two drama teachers (doktorsritgerd). Norwegian University of Science and Technology, Drándheimi.

Rúnar Helgi Andrason og Ársæll Már Arnarsson. (2013).Tilfellarannsóknir. Í Sigríður Halldórsdóttir (ritstjóri), Handbók i aðferðafreði rannsókna (bls. 497-509). Akureyri: Háskólinn á Akureyri.

Sawyer, R. K. (2003). Group creativity: Music, theater, collaboration. New York: Routledge.

Shafer, A. og Blakeslee, M. (2000). Music makes the difference: Music, brain development, and learning. Reston, VA: MENC's, The National Association for Music Education.

Siegel, D. J. (2007). The mindful brain: Reflection and attunement in the cultivation of well-being (Norton series on interpersonal neurobiology). New York: W.W. Norton.

Sóley Dröfn Davíðsdóttir. (2017). Náðu tökum á félagskvida. Reykjavík:Vaka-Helgafell.

Wittchen, H. U. og Fehm, L. (2003). Epidemiology and natural course of social fears and social phobia. Acta Psychiatrica Scandinavica, 108(417), 4-18. Sótt af https://onlinelibrary.wiley.com/doi/epdf/10.1034/j.1600-0447.108.s417.1.x

Wynnpaul,V.,Abrami, P. C. og Upitis, R. (2016). Self-regulation and music learning: A systematic review. Psychology of Music, 44(1), 55-74. Sótt af https://journals.sagepub.com/doi/pdf/10.1177/0305735614554639

Rannveig Björk Porkelsdóttir og Sólveig Pórðardóttir. (2020).

Söngleikur sem félagslegur vettvangur

Netla - Veftímarit um uppeldi og menntun. Menntavísindasvið Háskóla Íslands.

Sótt af http://netla.hi.is/greinar/2020/ryn/05

DOI: https://doi.org/10.24270/netla.2020.5 